\title{
Eucharystia pierwotnego Kościota w świetle Dziejów Apostolskich
}

W czasie Ostatniej Wieczerzy Apostołowie usłyszeli nakaz Jezusa: „To czyńcie na moją pamiątkę" ( tradycja antiocheńska i przekazała je nam zarówno w opisie ustanowienia Eucharystii w Ewangelii Łukasza $(22,19)$, jak i w Pawłowym wspomnieniu wydarzenia z Wieczernika w 1 Kor 11,24. Nakaz ten musiał bardzo głęboko

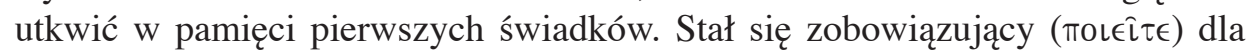
pierwotnej wspólnoty wyznawców Jezusa, bo wyznaczał swoistego rodzaju sposób przeżywania pamiątki Pana ${ }^{1}$. I nawet jeśli chodziło o wspominanie (memoriale) całego dzieła i osoby Jezusa², to nie ulega wątpliwości, że polecenie to zostało odniesione w pierwszej kolejności do samej Eucharystii, która od początku stała się uprzywilejowanym miejscem i sposobem przeżywania przez chrześcijan anamnezy Jezusa ${ }^{3}$.

W niniejszym artykule chcemy zastanowić się, w jaki sposób pierwotna wspólnota przeżywała Eucharystię. Weźmiemy pod uwagę księgę Dziejów Apostolskich, która zawiera historię pierwszych wspólnot chrześcijańskich. I chociaż dzieje te mogą wydawać się nam bardzo odległe, to przecież zawierają normy i wytyczne, które pozostają ciągle aktualne ${ }^{4}$.

W Dziejach Apostolskich nie znajdujemy nazwy Eucharystia. Pojawią się natomiast inne określenie - łamanie chleb lub łamać chleb. Zwrot ten, znany

${ }^{1}$ Por. G. Segalla (Teologia biblica del Nuovo Testamento. Tra memoria escatologica di Gesù e promessa del futuro regno di Dio, Torino 2006, 67), pisząc o poleceniu Chrystusa podczas Ostatniej Wieczerzy stwierdza, że ,il comando di Gesù è divenuto nel NT un testo prescrittivo e perciò performante".

${ }^{2}$ Por. H. Hübner, Biblische Theologie des Neuen Testaments, t. 3: Epilegomena, Göttingen 1995, 267; mówi on o „Gesamtmemoria Jesu”.

${ }^{3}$ Por. G. Segalla, Teologia biblica del Nuovo Testamento, 75.

${ }^{4}$ Por. W. Chrostowski, Eucharystia u pierwszych chrześcijan i dziś, Więź 1 (1987) 38. 
także w innych księgach Nowego Testamentu ${ }^{5}$, występuje 5 razy w Dziejach w trzech jednostkach literackich: a) dwa razy w summarium życia i liturgii

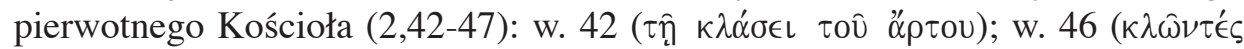
$\tau \epsilon \kappa \alpha \tau$ ' оîkov ' $\alpha \tau \tau o \nu)$; b) dwa razy w opisie pobytu Pawła w Troadzie w czasie

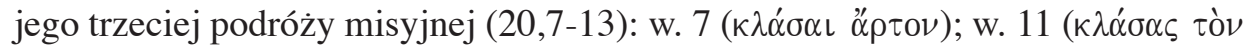
œ̊

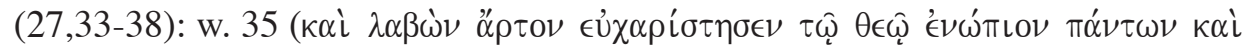
$\kappa \lambda \alpha ́ \alpha \alpha \varsigma)$. Na samym początku zwróćmy uwagę, że mamy zawsze do czynienia bądź z formą czasownikową $\kappa \lambda \alpha \dot{\omega} \omega$ bądź z rzeczownikiem odsłownym $\kappa \lambda \alpha ́ \sigma \iota \varsigma$

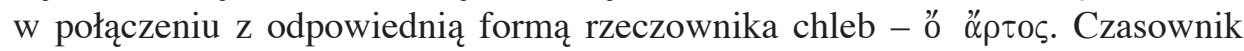
oznacza: „łamać coś”, „odłamywać”, „zakrzywiać”, „osłabiać”, „zniweczyć”. W Nowym Testamencie odnosi się zawsze do czynności łamania chleba ${ }^{7}$, której podmiotem jest sam Jezus (Mt 14,19; 15,36; 26,26; Mk 6,41; 8,6.19; 14,22; Łk 9,$16 ; 22,19 ; 24,30.35 ; 1$ Kor 11,24) lub Jego wyznawcy (Dz 2,42.46; 20,7.11; 27,35; 1 Kor 10,16).

Prześledzimy teraz trzy perykopy z Dziejów Apostolskich, zaczynając zawsze od interpretacji samego wyrażenia, ponieważ nie wszyscy egzegeci są zgodni, że chodzi o Eucharystię pierwotnego Kościoła. Niektórzy traktują to sformułowanie jako nawiązanie do zwykłego posiłku wspólnoty ${ }^{8}$. Po ustaleniu możliwej interpretacji eucharystycznej będziemy pytać o znaczenie Eucharystii dla pierwotnej wspólnoty chrześcijańskiej.

\section{1. Łamanie chleba we wspólnocie jerozolimskiej $(2,42-47)$}

Pierwszy tekst, w którym dwa razy odnajdujemy interesujące nas sformułowanie, to tzw. summarium, czyli syntetyczne streszczenie życia i liturgii pierwotnej gminy chrześcijańskiej w Jerozolimie. Czytamy, że ci, którzy zostali

\footnotetext{
${ }^{5}$ Por. R.A. Sikora, Gest „łamania chleba” w Nowym Testamencie, w: Biblia o Eucharystii, red. S. Szymik, Lublin 1997, 111-126.

${ }^{6}$ R. Popowski, Stownik grecko-polski Nowego Testamentu (PSB), Warszawa 1997, 179.

${ }^{7}$ Por. W. Surmiak, „Łamanie chleba” w Nowym Testamencie ( $Ł k$ 24,35 i Dz 2,42), ŚSHT 36 (2003) 404.

${ }^{8}$ K. Romaniuk (Studia nie tylko nad św. Pawłem, Poznań 1999) w artykule: Czy określenie „łamanie chleba” odnosi się w Nowym Testamencie do Eucharystii (s. 146-152) wymienia egzegetów, którzy opowiadają się za nieeucharystyczną interpretacją formuły, jak i tych, którzy interpretują to wyrażenie jako odniesienie do Eucharystii.

$9 \mathrm{Na}$ temat historii interpretacji summariów zob. J. Łach, Rola gminy jerozolimskiej w pierwotnym Kościele (Dz 2,42-47; 4,32-35; 5,12-16), w: Scrutamini Scripturas, Fs. S. Łach, Kraków 1980, 84-89. Autor omawia także strukturę literacką summarium, zob. s. 90-91.
} 
ochrzczeni w imię Jezusa $(2,41)$, trwali w nauce Apostołów $i$ we wspólnocie,

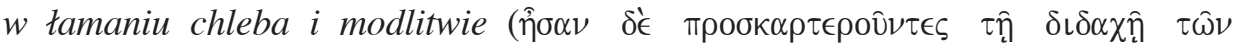

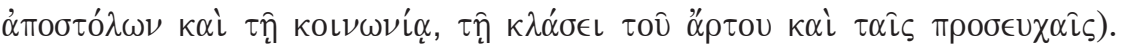

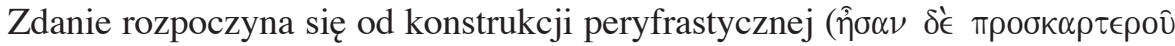
$\nu \tau \epsilon \varsigma)$, od której zależą kolejne cztery rzeczowniki w celowniku, określające życie nowo ochrzczonych wyznawców Chrystusa. Werset nasz przy pomocy spójnika

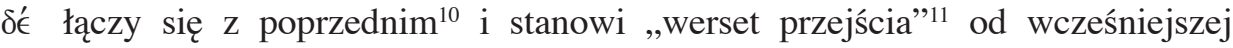
jednostki literackiej (2,37-41) do kolejnej (2,42-48), co w konsekwencji oznacza, że opisuje sposób życia nie tylko nowych uczniów Jezusa, którzy zostali ochrzczeni w Jego imię $(2,41)$, ale charakteryzuje życie wspólnoty jako takiej.

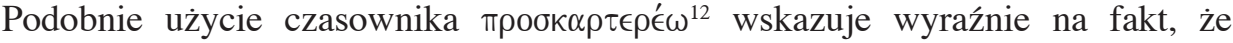
przyjęcie chrztu zobowiązuje chrześcijan do ściśle określonej stałej postawy, która zostaje zdefiniowana dalej i być może w zamyśle Łukasza staje się przykładem godnym naśladowania dla każdej wspólnoty uczniów Jezusa.

Życie i obrzędy liturgiczne wspólnoty chrześcijańskiej zostały opisane przy pomocy czterech rzeczowników, ułożonych w dwie pary połączone spójnikiem kaí. Pierwsze dwa odnoszą się do życia uczniów Jezusa: trwanie w nauce

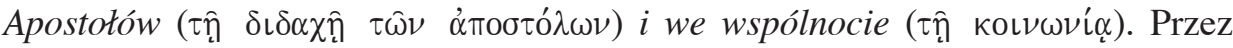
naukę Apostołów Łukasz rozumie nie tylko konkretne pouczenie apostolskie, które otrzymuje wspólnota, ale całokształt nauczania apostolskiego, które ma znaczenie normatywne dla chrześcijan, ponieważ pochodziło od naocznych świadków słów i dzieł Jezusa oraz stanowiło wypełnienie polecenia samego Chrystusa, aby Apostołowie dawali świadectwo i głosili prawdę Ewangelii. Na pierwszym miejscu Łukasz wymienia zatem trwanie w nauce Apostołów, bo właśnie to gwarantowało zachowanie nieskażonej pamięci o Jezusie przekazanej przez naocznych świadków. Warto też zwrócić uwagę, że Autor pisze o nauce Apostołów, a nie Jezusa. To określenie jest z pewnością szersze i obejmuje także doświadczenie paschalne, w świetle którego nauczanie Jezusa zostało zinterpretowane i odniesione na nowo do życia wspólnoty. Temu wiernemu przekazywaniu słów i czynów Jezusa towarzyszyła troska o zachowanie tradycji, ale jednocześnie o aktualizację didache Pana w konkretnej sytuacji wspólnoty wierzących. Wyznawanie wiary w Chrystusa zmartwychwstałego domaga się także nowego sposobu życia, konkretnych postaw, które wspólnota odnajdywała w przekazie apostolskim ${ }^{13}$.

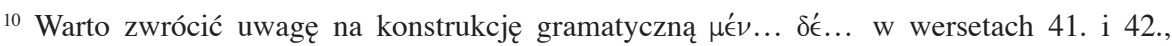
która wskazuje na łączność: „z jednej strony... z drugiej...”, zob. G. Rossé, Atti degli Apostoli. Commento esegetico e teologico, Roma 1998, 164.

${ }^{11}$ Por. G. Schneider, Gli Atti degli Apostoli, t. 1, Brescia 1985, 397-398.

${ }^{12}$ Por. S. Pisarek, Idea „trwania” (proskartérēsis) w Dziejach Apostolskich, ŚSHT 22 (1989) 211-223.

${ }^{13}$ Por. W. Chrostowski, Eucharystia u pierwszych chrześcijan i dziś, 39. 


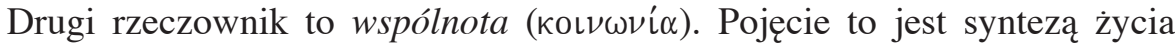
chrześcijańskiego ${ }^{14}$ i niesie $\mathrm{W}$ sobie bardzo bogate znaczenie teologiczne, stąd ma długą historię interpretacji. Egzegeci różnie wyjaśniają znaczenie tego terminu w naszym kontekście. Interpretacje można sprowadzić do czterech form: 1) koinōnia jako wspólnota lub łączność braterska, gdzie główny akcent spoczywa na duchowej jedności istniejącej między członkami wspólnoty; b) jako łączność apostolska między wiernymi a Apostołami, w tym sensie wyrażenie to byłoby wyjaśnieniem formuły trwali w nauce Apostołów; c) jako uczestnictwo przy wspólnym stole (agapa); d) jako wymiana dóbr materialnych, wspólnotowe uczestnictwo w dobrach materialnych ${ }^{15}$.

Jakkolwiek będziemy rozumieli trwanie we wspólnocie, to owa jedność wspólnoty wypływa zawsze z jedności z Jezusem, a w Nim i przez Niego oznacza jedność z Bogiem. Realizuje się dzięki Duchowi Świętemu, którym Bóg obdarzył wierzących. Centrum tej jedności pozostaje zawsze Jezus Chrystus - Zmartwychwstały Pan oraz powołanie chrześcijan do wspólnoty z Jezusem. $\mathrm{Z}$ głębokiego przeżywania tej jedności rodzi się przełamywanie wszelkiego rodzaju barier, pokonywanie podziałów społecznych, kulturowych i etnicznych. Ze owej świadomości bliskości Pana wypływał duch braterstwa, miłości, otwarcia na drugiego człowieka, dzielenia się dobrami.

Kolejne dwa określenia odnoszą się do liturgii pierwotnego Kościoła:

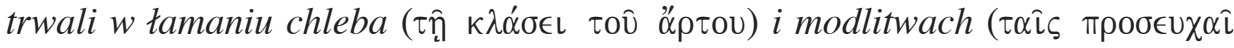
§). Na trzecim miejscu odnajdujemy zatem sformułowanie, które interesuje nas najbardziej - łamanie chleba. Co oznaczał ten gest? Czy odnosił się do Eucharystii? Zdania egzegetów są tutaj bardzo podzielone ${ }^{16}$. W każdym opracowaniu przytacza się opinie za eucharystyczną interpretacją powyższej formuły lub argumenty, które mogą przemawiać, że chodziło raczej tutaj o zwykły posiłek (agapę) chrześcijański.

Podobne sformułowanie odnajdujemy jeszcze tylko w Łk 24,35, kiedy to

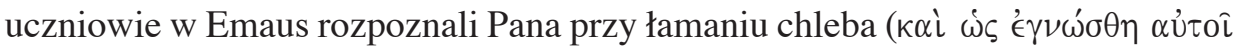

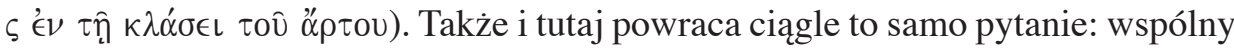
posiłek czy Eucharystia? Jeśli to wydarzenie potraktujemy na płaszczyźnie historycznej to mamy sporo problemów, aby uznać, że chodzi o sprawowanie Eucharystii ${ }^{17}$. Nie wolno jednak nigdy zapominać, że opowiadanie o uczniach w Emaus jest pisane z perspektywy popaschalnej. Powstaje we wspólnocie,

14 Por. S. Mędala, Pojęcie „koinōnia” w Nowym Testamencie jako synteza życia chrześcijańskiego, w: W posłudze Słowa Pańskiego, Fs. J. Kudasiewicz, red. S. Bielecki H. Ordon - H. Witczyk, Kielce 1997, 329-346.

15 Tamże, 344.

${ }^{16}$ Por. przyp. 8.

${ }^{17}$ Por. W. Surmiak, „Łamanie chleba” w Nowym Testamencie (Łk 24,35 i Dz 2,42), 406-208. 
która na pamiątkę Jezusa sprawuje już Eucharystię jako uobecnianie gestów z Ostatniej Wieczerzy według polecenia Mistrza, aby czynić to na Jego pamiątkę. Uświadomienie sobie tej perspektywy jest niezwykle ważne dla eucharystycznej interpretacji czynności łamania chleba. Bo właśnie w tym szczególnym wydarzeniu, jakim była Eucharystia, pierwotna wspólnota wspominała słowa i czynności Jezusa, przeżywając je nie tylko jako przeszłość, ale aktualizując je w teraźniejszości, dostrzegając obecność Pana na nowy sposób. Celebrując Wieczerzę Pańska ustanowioną przez Jezusa, chrześcijanie uczyli się odkrywać w pozornej nieobecności, nową i rzeczywistą obecność Chrystusa ${ }^{18}$.

Skoro opowiadanie o uczniach w Emaus jest literacką konstrukcją Łukasza, to $\mathrm{z}$ perspektywy popaschalnej wydaje się zasadne stawianie pytania nie o to, czy Jezus w Emaus sprawował Eucharystię, ale trzeba się pytać o to, czy Łukasz zamierzał w tym miejscu nawiązać do praktyki sprawowania Eucharystii ${ }^{19}$.

Najpierw trzeba zauważyć, że cały kontekst, szczególnie werset 30, który mówi o czynnościach Jezusa: zajął z nimi miejsce u stołu, wziąt chleb, odmówił błogosławieństwo, połamał go $i$ dawał im, przypomina zarówno ustanowienie Eucharystii (Łk 22,19), jak i opis rozmnożenia chleba (Łk 9,16). Dla samego Łukasza, a także wspólnoty Kościoła, jest to klasyczny sposób nawiązania do Eucharystii $^{20}$. Nawet, jeśli jest to normalna sekwencja czasowników związana z żydowską ucztą, a samo określenie łamanie chleba mogło określać początek albo niekiedy zakończenie posiłku ${ }^{21}$, to w pierwotnym chrześcijaństwie nabiera ono szczególnego charakteru czynności przypominającej dzieło samego Chrystusa: rozmnożenie chleba i sakrament Eucharystii podczas Ostatniej Wieczerzy. Znaczący jest także fakt, że samo określenie pojawia się zawsze w tych dwóch kontekstach: ustanowienia Eucharystii ( $\kappa \lambda \dot{\alpha} \omega$ Mt 26,26; Mk 14,22; Łk 22,19;

${ }^{18}$ R. Laurentin, Jezus Chrystus prawdziwie obecny. Eucharystia - Kościót - Jedność, Kraków 1998, 107.

${ }^{19}$ Por. W. Rakocy, Emaus - zmierzajac na spotkanie ze zmartwychwstałym Panem (Łk 24,1335), w: Biblia o Eucharystii, red. S. Szymik, Lublin 1997, 98. 107.

${ }^{20}$ Por. J.A. Fitzmyer, The Gospel according to Luke X-XXIV, New York 1985, 1558; zob. także

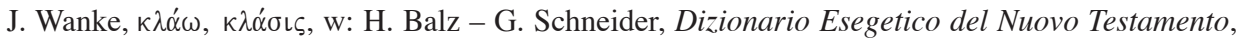
t. II, Brescia 1998, 44.

${ }^{21}$ R. Sikora, (Gest „łamania chleba” w Nowym Testamencie, 116) stwierdza: „Wprawdzie czynność łamania chleba jest powszechnym zjawiskiem na Wschodzie, ale samo wyrażenie łamanie

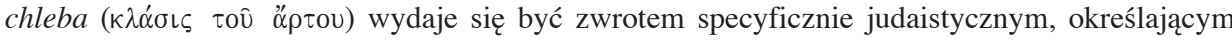
początek - albo niekiedy zakończenie posiłku - zarówno zwykłego, jak i uczty o charakterze sakralnym. Zasadniczo zwrot ten nie jest znany Grekom. W Septuagincie pojawia się dwa razy w Jr 16,7 i Lm 4,4, gdzie jest odpowiednikiem hebrajskiego zwrotu paras lehem. Nie występuje on w ogóle w dziełach Filona i Józefa Flawiusza. Łacińskie panem frangere można znaleźć w nielicznych tekstach autorów rzymskich, ale jedynie jako zwrot poetycki, nieposiadający żadnych konotacji religijnych”. 
1 Kor 11,24) oraz w opisach cudownych rozmnożeń chleba (Mt 14,19; 15,36; Mk

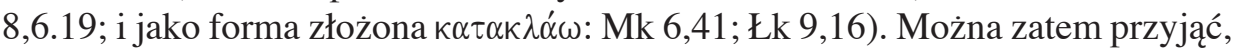
że sam zwrot rozumiany był już w pierwotnym chrześcijaństwie niemalże jako techniczne określenie Eucharystii ${ }^{22}$, co stało się powszechne w późniejszych wiekach (Didache 9,3; 14,1; Ignacy Antiocheński, Eph. 20,2)23.

„Ponadto - jak pisze ks. Waldemar Rakocy - wydaje się, że Łukasz zamierza nawiązać do praktyki sprawowania Wieczerzy Pańskiej w jego czasach. Taki jest ogólny wydźwięk opisanej sceny. Inaczej jak wytłumaczyć to, że uczniowie rozpoznali Jezusa w zwykłym geście łamania chleba (podczas zwykłego posiłku), a nie poznali Go wcześniej w Jego uwielbionym człowieczeństwie i w trakcie wyjaśniania im Pism? Wyrażenie łamanie chleba ma dla Łukasza wyjątkowe znaczenie. Chce przez nie wskazać na celebrowaną w jego czasach pamiątkę męki i zmartwychwstania Chrystusa" 24 . W ten sposób rozpoznanie Pana w łamaniu chleba uświadamiało uczniom ich udział nie tylko w Jezusowej ofierze życia, ale także w zwycięstwie Chrystusa nad śmiercią. Gest łamania chleba stawał się zatem nie tylko znakiem Chrystusa Ukrzyżowanego, ale i Zmartwychwstałego. To właśnie w tym znaku-pamiątce wspólnota dostrzegała i przeżywała obecność Zmartwychwstałego Chrystusa. Ten nowy sposób obecności Pana nadawał znakowi tej obecności - łamanemu chlebowi głęboki wymiar egzystencjalny, przeżywany jako trwanie w nauce Apostołów $i$ wspólnocie.

Wydaje się zatem jasne, że kiedy w Dz 2,42 Łukasz pisze o trwaniu wierzqcych $w$ tamaniu chleba, ma na myśli Eucharystię ${ }^{25}$. Na poparcie takiej interpretacji można przytoczyć - za ks. J. Kudasiewiczem - następujące argu-

${ }^{22}$ Inaczej K. Romaniuk (Studia nie tylko nad św. Pawłem, 152): „Ani formuła łamanie chleba, ani forma osobowa czasownika łamać w połączeniu z rzeczownikiem chleb nie mogą być w Nowym Testamencie uważane za określenie techniczne sprawowania Eucharystii. Mogą ten obrzęd oznaczać, ale mogą się też odnosić do spożywania jakiegoś posiłku, niekoniecznie sakralnego". W dalszej części rozważań Autor przyznaje jednak, że formuła łamanie chleba w ,Dz 2,42 stanowi nawiązanie do Eucharystii, natomiast w Łk 24,35 nie ma związku z Eucharystią i oznacza zwykły posiłek Jezusa strudzonego długą podróżą". Za interpretacją eucharystyczną opowiada się G. Segalla, Teologia biblica del Nuovo Testamento, 232.

23 Por. J. Taylor, La fraction du pain en Luc-Actes, w: The Unity of Luke-Acts, red. J. Verheyden, Leuven 1999, 281-295; na temat interpretacji formuły łamanie chleba u Ojców Kościoła i w liturgii, zob. W. Surmiak, „Łamanie chleba” w Nowym Testamencie ( $€ k$ 24,35 i Dz 2,42), 410-412.

${ }^{24}$ W. Rakocy, Emaus - zmierzając na spotkanie ze zmartwychwstałym Panem (Łk 24,13-35), 107.

25 Por. G. Rossé (Atti degli Apostoli, 166), który zwraca uwagę, że skoro w judaizmie określenie łamać chleb połączone z błogosławieństwem oznaczało początek uczty, to u Łukasza wyrażenie to - według zasady pars pro toto - oznacza celebrację Eucharystii. Podobnie za interpretacją eucharystyczną opowiada się F. Bianchi (Atti degli Apostoli, Roma 2003, 40) oraz P.-É. Langevin (Les Actes des apôtres. Introduction générale, traduction et commentaire, Montréal 2003, 51); W. Kurz, Atti degli Apostoli, Brescia 1993, 36. 
menty: 1) tłumaczenie syryjskie wyrażenia łamanie chleba oddaje wprost przez łamanie Eucharystii; 2) rodzajnik określony przed rzeczownikiem chleb wskazuje, że chodzi o wyrażenie techniczne, nie o jakiś ogólnie wzięty chleb (wtedy rzeczownik nie byłby poprzedzony rodzajnikiem określonym), lecz o konkretny, specjalny chleb (stąd rodzajnik); 3) pozostałe określenia z wersetu wskazują na kontekst religijny, a nawet kultyczny (modlitwa, trwanie w nauce Apostołów), stąd ów kontekst determinuje eucharystyczny sens naszej formuły ${ }^{26}$. Warto przytoczyć jeszcze jeden argument. W 1 Kor 10,16 czytamy: Kielich błogosławieństwa, który błogosławimy, czy nie jest udziałem we Krwi Chrystusa? Chleb, który łamiemy, czyż nie jest udziałem w Ciele Chrystusa?

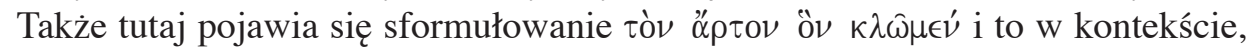
co do którego nie ma żadnych wątpliwości, że chodzi o Eucharystię pierwotnego Kościoła $^{27}$. Co prawda Łukasz nie wspomina kielicha, ale nie jest wykluczone, że Autor używa wyrażenia łamanie chleba jako pars pro toto na określenie Uczty Pańskiej ${ }^{28}$. Ponadto w Ewangelii Jana opis rozmnożenia chleba został umieszczony na początku mowy eucharystycznej (6,1-15), a zatem dla Ewangelisty cud Jezusa jest zapowiedzią Eucharystii. Jan pisze, że po cudownym rozmnożeniu

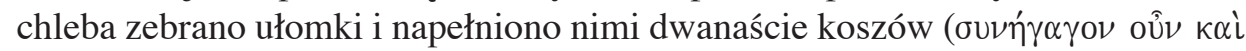

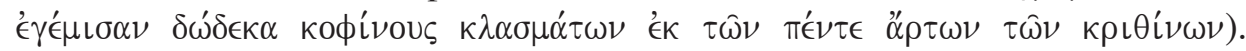
W wyrażeniu $\kappa \lambda \dot{\alpha} \sigma \mu \alpha$ (ułomki), które występuje także w synoptycznych opisach rozmnożenia chleba (Mt 14.20.37; Mk 8,8.19.20; Łk 9,7), można widzieć skoja-

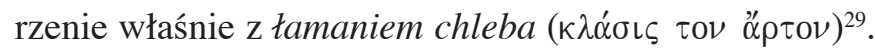

Można by nawet przyjąć, jak chcą tego niektórzy komentatorzy, że kiedy mowa jest o łamaniu chleba, chodzi tutaj o posiłek wspólnoty, podczas którego celebrowano Eucharystię. W ten sposób Łukasz nie oddzielałby tych dwóch rzeczywistości ${ }^{30}$, które wspomina także tradycja Pawłowa (1 Kor 11,17-22) ${ }^{31}$. Trzeba jeszcze zwrócić uwagę na jeszcze jeden element przemawiający za interpretacją eucharystyczną naszego wyrażenia. Otóż Łukasz, kiedy mówi o zwykłym posiłku i przyjmowaniu pokarmu, używa innych czasowników: '́đố $\omega$

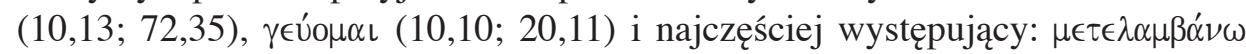

${ }^{26}$ J. Kudasiewicz, Eucharystia w życiu pierwotnego Kościoła, w: Eucharystia - miłość i dziękczynienie, red. W. Słomka - A.J. Nowak, Lublin 1992, 23.

${ }^{27}$ Por. K. Romaniuk, Studia nie tylko nad św. Pawłem, 152.

${ }^{28}$ Por. S. Pisarek, Idea „trwania” (proskartérēsis) w Dziejach Apostolskich, 217. Zob. także

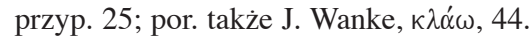

${ }^{29}$ Por. J. Kudasiewicz, Eucharystia w życiu pierwotnego Kościoła, 29.

${ }^{30}$ Por. G. Schneider, Gli Atti degli Apostoli, 398 oraz W.H. Willimon, Atti degli apostoli, Torino 2003, 53.

${ }^{31}$ Por. G. Barbaglio, La Prima Lettera ai Corinzi, Bologna 1995, 564-565; R. Fabris, Prima Lettera ai Corinzi, Milano 1999, 149-152; por. także D. Marguerat, Les Actes des Apôtres (1-12), Genève 2007, 108. 


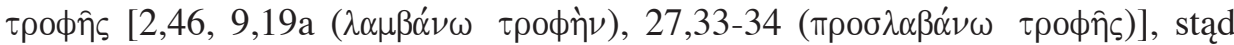
wydaje się, że określeniu łamanie chleba nadaje nowe znaczenie, inne niż tylko określenie zwykłego posiłku ${ }^{32}$.

Pozostaje jeszcze do podkreślenia wspólnotowy wymiar łamania chleba. W tym kontekście warto zauważyć, że wersja łacińska Kodeksu Bezy oraz Wulgata posiadają wariant tekstualny - in communicatione fractionis panis. „Celebracja Sakramentu nie tyle zmierza do zaspokojenia potrzeb indywidualnej pobożności, ile akcentuje aspekt społeczny, zbiorowego powołania do zbawienia. Najwłaściwszym kontekstem sprawowania Eucharystii jest celebracja we wspólnocie zebranej w jednym duchu i utwierdzonej w przeświadczeniu, że stanowi «światło» i «sól»w dziele przetwarzania wielkiej rodziny ludzkiej. Widziana w tej perspektywie Eucharystia jest spoiwem Kościoła i znakiem jedności rozmaitych wspólnot lokalnych. Przyczynia się do budowania prawdziwej jedności" 33 .

Czwartą rzeczywistością, która nadaje nowy wymiar życiu wspólno-

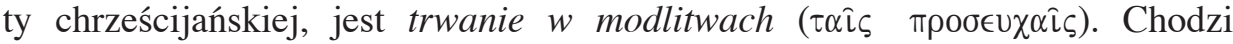
o modlitwę wspólnotową. Już w 1,14 czytamy, że wspólnota trwała jednomyślnie

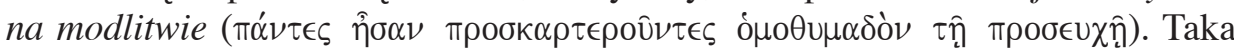
modlitwa to naturalne przedłużenie Eucharystii, w której znajduje swoje źródło. Modlitwa wspólnoty i pojedynczego ucznia Jezusa jest „miejscem” i „sposobem” przedłużenia dziękczynienia właściwego Eucharystii.

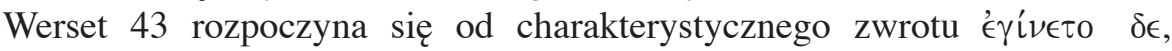
oznaczającego nowy początek narracji. Autor chce teraz przedstawić czytelnikowi już nie tylko sytuację nowo ochrzczonych, ale przechodzi do ogólnej charakterystyki wspólnoty pierwotnego Kościoła. Najpierw zwraca uwagę na reakcję ludzi, którzy byli świadkami czynów i cudów Apostołów. Wzbudzały one bojaźn (фóßos), tzn. „święty lęk” wobec wielkich dzieł Boga, które objawiał przez ręce Apostołów.

Kolejne wersety (44-45) mówią o wspólnocie dóbr materialnych. Czytamy, że ci wszyscy, co uwierzyli, przebywali razem $i$ wszystko mieli wspólne. Sprzedawali majątki i dobra i rozdzielali je każdemu wedtug potrzeby. Autor bardzo mocno podkreśla ów wspólnotowy wymiar posiadania tego, co materialne. Miało to służyć wspólnocie, a szczególnie tym, którzy byli w jakiejkolwiek potrzebie. Dla naszych rozważań wydaje się być bardzo znaczący fakt, że przed drugim nawiązaniem do sprawowania Eucharystii (w. 46) wyraźnie jest mowa o wrażliwości wspólnoty na potrzeby innych, szczególnie najbardziej potrzebujących. W takim kontekście Eucharystia jawi się jako urzeczywistnianie

\footnotetext{
${ }^{32}$ Por. N. Casalini, Il pasto del Signore, SBFLA 50 (2000) 102.

${ }^{33} \mathrm{~W}$. Chrostowski, Eucharystia u pierwszych chrześcijan i dziś, 41.
} 
w teraźniejszości (życiu wspólnoty) wezwania samego Chrystusa do pełnienia dzieł miłosierdzia. Tak przeżywana Eucharystia tworzy autentyczną wspólnotę Kościoła $^{34}$.

Kolejne zdanie summarium (w. 46) informuje nas, że chrześcijanie codziennie trwali jednomyślnie $w$ światyni, a łamiac chleb $w$ domu, przyjmowali

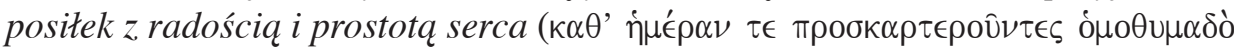

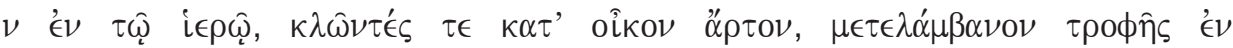

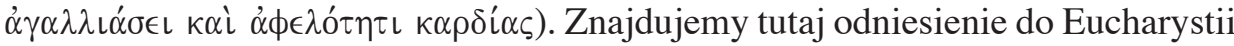

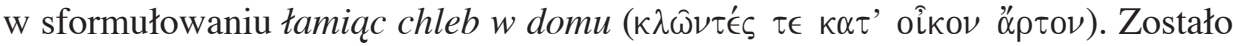
ono poprzedzone informacją, że chrześcijanie codziennie trwali na modlitwie w świątyni. Konstrukcja gramatyczna wskazuje raczej, że określenie codzien-

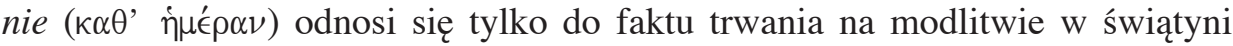
jerozolimskiej ${ }^{35}$, dlatego trudno byłoby wnioskować na podstawie tej informacji, że chodzi także o codzienne sprawowanie Eucharystii ${ }^{36}$. Drugie określenie

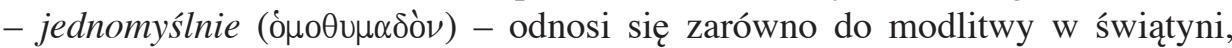
jak i trwania „w domu" ${ }^{37}$. Nawet jeśli świątynia pozostawała nadal centrum modlitwy dla uczniów Jezusa, to mieli oni także inne, nowe miejsca spotkań na modlitwę, którymi były domy chrześcijan. $Z$ jednej więc strony mamy ideę kontynuacji (świątynia), a z drugiej - dom jako miejsce wspólnotowej modlitwy

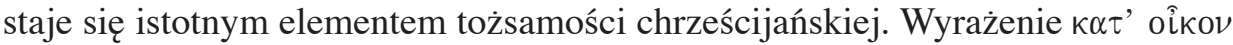
można różnie przełożyć: „,W domu”, „,z domu do domu”, „w różnych domach”, „w każdym domu” ${ }^{38}$, ale zawsze oznacza wspólnotę Kościoła (Rz 16,5; 1 Kor 16,19; Flm 2; Kol 4,15), która zbierała się w jakimś domu, najczęściej będącym własnością kogoś, kto przynależał do wspólnoty ${ }^{39}$. Było to miejsce zgromadzenia i celebrowania pamiątki Jezusa poprzez łamanie chleba, czego potwierdzenie znajdziemy dalej w Dz 20,7. Zauważmy, że tym razem czynność wyrażona została przez formę imiesłowu czasu teraźniejszego w liczbie mnogiej czasownika $\kappa \lambda \alpha \omega$, natomiast brakuje rodzajnika określonego przed rzeczownikiem chleb.

${ }^{34}$ Por. L. Pacomio, Dacci ogni giorno il nostro pane. L'Eucarestia secondo Luca, Roma 1983, 75-86.

35 Por. G. Schneider, Gli Atti degli Apostoli, 401. Inaczej W. Chrostowski (Eucharystia u pierwszych chrześcijan i dziś, 43), który uważa, że określenie codziennie odnosi się tak do modlitwy w świątyni, jak i do uczt eucharystycznych sprawowanych w domach.

${ }^{36}$ Por. G. Rossé, Atti degli Apostoli, 169, przyp. 240.

${ }^{37}$ Por. N. Casalini, Il pasto del Signore, 102.

${ }^{38}$ Por. D. Marguerat, Les Actes des Apôtres (1-12), 107: „dans chaque maison”.

${ }^{39}$ Por. H. Langkammer, „,Kościoły domowe” w Nowym Testamencie, w: Biblia o rodzinie, red. G. Witaszek, Lublin 1995, 7-12. Inaczej zdanie to interpretuje N. Casalini (Il pasto del Signore, 100), który podkreśla, że nie chodzi o wspólne spotkanie w jakimś domu i spożywanie pamiątki Pana, ale tekst mówi, że każdy spożywał posiłek we własnym domu. Interpretuje on określenie „w domu" w sensie dystrybutywnym. 
Niektórzy sądzą zatem, że chodzi tutaj raczej o zwykły posiłek oraz zwykły chleb, który spożywano na znak wspólnoty, być może poświęcony tylko specjalnym błogosławieństwem ${ }^{40}$. Jak już powiedzieliśmy wcześniej, w pierwszym wieku Uczta Eucharystyczna była połączona z agapą, zatem określenie to może oznaczać obie rzeczywistości jednocześnie ${ }^{41}$.

Łukasz podkreśla mocno, że sprawowanie Eucharystii dokonywało się

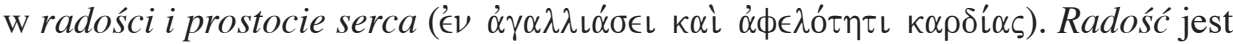
znakiem nowego czasu zbawienia, przeżywania obecności Pana ${ }^{42}$. Prostota ${ }^{43}$ serca to wyrażenie semickie, oznaczające świadomy i czynny udział wszystkich wierzących w świętej uczcie na cześć Zmartwychwstałego Pana ${ }^{44}$.

Ostatni werset summarium (w. 47) mówi nam o reakcji ludzi „z zewnątrz”, którzy byli pełni podziwu dla nowego stylu życia uczniów Jezusa: Wielbili Boga, a cały lud odnosit się do nich życzliwie. Pan zaś przymnażat im codziennie tych, którzy dostępowali zbawienia. To bardzo ważny szczegół. Modlitwa, Eucharystia mają swój wymiar misyjny o tyle, o ile są źródłem przemiany życie ucznia Jezusa, i to w taki sposób, że jego życie staje się wielbieniem Boga i sposobem dawania przekonywającego świadectwa o wielkich dziełach Boga. Tylko takie autentyczne świadectwo wzbudza życzliwość innych i może pociągać ich do Jezusa, aby i oni mogli dostąpić zbawienia.

\section{2. Łamanie chleba w Troadzie (20,7-12)}

Kolejna wzmianka o Eucharystii znajduje się w rozdziale 20, gdzie Łukasz opowiada o trzeciej podróży Pawła. W czasie pobytu w Troadzie miało miejsce wydarzenie opisane w ww. 7-13. Chodzi o wskrzeszenie młodzieńca o imieniu Eutych, który zmorzony snem wypadł z trzeciego piętra, kiedy Paweł długo przemawiał do zebranej wspólnoty. Dwa interesujące nas sformułowania znajdujemy w ww. 7 i 11.

${ }^{40}$ Por. D. Rops, Życie codzienne w Palestynie w czasach Chrystusa, Poznań 1965, 278-289; cytuję za S. Pisarek, Idea „trwania” (proskartérēsis) w Dziejach Apostolskich, 217.

${ }^{41}$ Por. G. Rossé, Atti degli Apostoli, 169.

${ }^{42}$ Por. I.H. Marshall, Gli Atti, 107.

${ }^{43}$ Użyte słowo to hapax w Nowym Testamencie, zob. G. Rossé, Atti degli Apostoli, 169, przyp. 243. Autor zwraca także uwagę, że być może w tej bardzo pozytywnej charakterystyce wspólnych posiłków Łukasz chce oddalić wszelkie podejrzenia i oskarżenia (nawet o orgie), które mogły się pojawić ze strony przeciwników chrześcijan.

${ }^{44}$ Por. W. Chrostowski, Eucharystia u pierwszych chrześcijan i dziś, 43. 
$\mathrm{Na}$ samym początku opowiadania czytamy, że wspólnota zebrała się

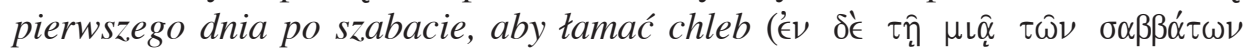

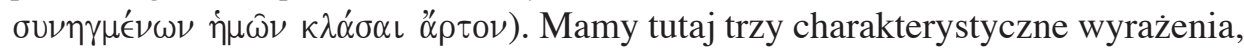
które wskazują na celebrację eucharystyczną. Pierwsze sformułowanie $\epsilon \nu$

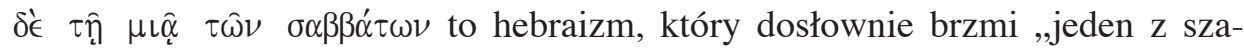
batów", a oznacza $w$ pierwszy dzień po szabacie, a więc w niedzielę, która dla chrześcijan jest pamiątką zmartwychwstania Jezusa (Łk 24,1; Mk 16,2) i staje się dniem Pańskim (Ap 1,10; Didache 14,1) ${ }^{45}$. Jest to najstarsze świadectwo, że chrześcijanie zbierali się na modlitwę i pamiątkę Pana $w$ innym dniu niż żydowski szabat ${ }^{46}$. Trudno jest odpowiedzieć jednoznacznie, czy chodzi o sobotni wieczór czy niedzielny. Jeśli przyjmiemy, że Łukasz liczy czas według sposobu żydowskiego, to wydarzenie miałoby miejsce w sobotę wieczorem, kiedy już rozpoczyna się niedziela, jeśli natomiast według sposobu rzymskiego, to $w$ niedzielę wieczorem ${ }^{47}$. Dla naszych rozważań jest to drugorzędny problem, bo jakąkolwiek przyjmiemy chronologię, to tekst jasno precyzuje, że Eucharystia ma miejsce w niedzielę - dzień wspominania wydarzenia, które miało miejsce

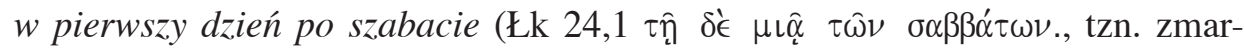
twychwstania Chrystusa).

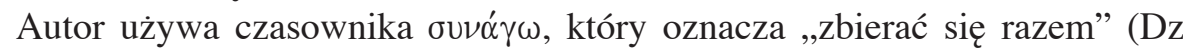
4,31; Mt 18,20; 1 Kor 5,4; Didache 16,2; 1 Clem 34,7) i w łączności z określeniem

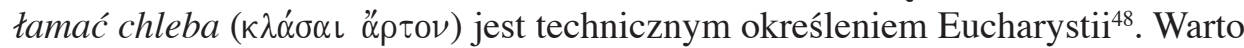
jeszcze zwrócić uwagę, że mamy pewien element, który może potwierdzać interpretację eucharystyczną wyrażenia. Otóż Autor wspomina, że Paweł przedłużył swoje przemówienie aż do północy. Trudno jest wyobrazić sobie, aby wspólnota czekała na zwyczajny posiłek tak długo. „Należy sądzić, że każdy spożył już wcześniej posiłek - teraz celebrują tylko Eucharystię" ${ }^{\text {"49. Za }}$ interpretacją eucharystyczną może przemawiać jeszcze jeden ważny argument. Otóż, podobnie jak dla opisania zwykłego posiłku, Łukasz używa innych cza-

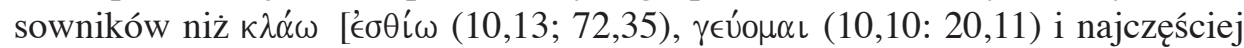

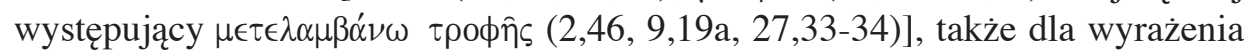

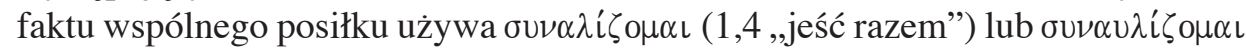

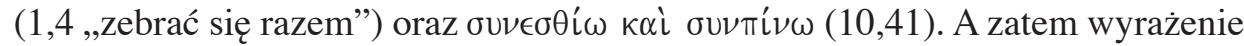

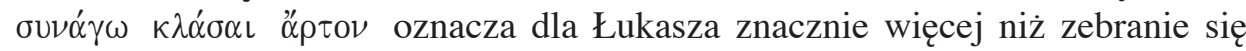
w celu spożycia wspólnego posiłku.

\footnotetext{
${ }^{45}$ Por. G. Rossé, Atti degli Apostoli, 712, zwł. przyp. 39.

${ }^{46}$ Por. I.H. Marshall, Gli Atti, 460, zwł. przyp. 13.

47 Por. G. Schneider, Gli Atti degli Apostoli, t. 2, Brescia 1986, 377, zwł. przyp. 377; I.H. Marshall, Gli Atti, 461.

${ }^{48}$ Por. G. Rossé, Atti degli Apostoli, 712.

${ }^{49}$ W. Rakocy, Emaus - zmierzajac na spotkanie ze zmartwychwstałym Panem (Łk 24,13-35), 108.
} 
Zanim jednak wspólnota mogła uczestniczyć w samym geście łamania

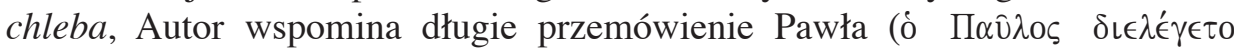

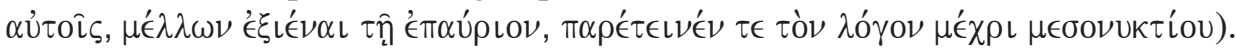
Kontekst wyraźnie sugeruje, że chodzi o mowę pożegnalną, bo następnego dnia Paweł zamierza opuścić wspólnotę w Troadzie i udać się w dalszą drogę. Ale czy chodzi tylko o pożegnanie? Otóż na określenie przemówienia Pawła używa się czasownika $\delta\left\llcorner\alpha \lambda \epsilon^{\prime} \gamma o \mu \alpha \iota\right.$, który w innych miejscach oznacza nauczanie Apostoła w synagodze $(17,2.17 ; 18,4.19 ; 19,8)$. W ten sposób zebranie liturgiczne rozpoczyna się od nauczania apostolskiego, którego przedmiotem było głoszenie Ewangelii, a także odpowiadanie na szczegółowe kwestie, które mogły dotyczyć życia wspólnoty i pojedynczych chrześcijan ${ }^{50}$. Ten aspekt był szczególnie bliski Łukaszowi, który już w opowiadaniu o uczniach w Emaus mocno podkreśla, że zanim rozpoznali Jezusa w trakcie łamania chleba, najpierw On sam wyjaśniał im Pisma (Łk 24,25-27.30.35) ${ }^{51}$. Tak więc od samego początku słuchanie Słowa poprzedzało i przygotowywało tamanie chleba.

Kolejne wersety (ww. 8-9) opisują wypadek młodzieńca Eutycha w następujący sposób: Wiele lamp paliło się w górnej sali, gdzie byliśmy zebrani. Pewien młodzieniec, imieniem Eutych, siedziat na oknie pograżony w głębokim śnie. Kiedy Pawet przedłużat przemówienie, zmorzony snem spadt z trzeciego piętra na dót. Podniesiono go martwego. Interesujące dwa szczegóły znajdują się w na początku, kiedy mowa, że w górnej sali paliło się wiele lamp (

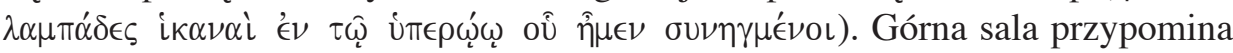
miejsce Ostatniej Wieczerzy (Łk 22,12), miejsce modlitwy Apostołów (Dz 1,13) oraz epizod wskrzeszenia Tabity (Dz 9,37.39). W sali paliło się wiele lamp. W historii egzegezy pojawiło się wiele interpretacji tego szczegółu ${ }^{52}$. Tutaj przywołuję tylko te, które w jakiś sposób potwierdzają, że mamy do czynienia z liturgią Eucharystii. Być może są to lampy zapalone na potrzeby liturgii dla podkreślenia obecności Pana oraz dla wyrażenia uroczystego i radosnego charakteru modlitwy. Być może wspomniane lampy posiadają walor symboliczny i oznaczają, że miejsce spotkań chrześcijan, gdzie głosi się słowo Boże i łamie chleb, jest pełne światła, tzn. życia.

Paweł poprzez czynności podobne do gestów Eliasza i Elizeusza (1 Krl 17,17-24 i 2 Krl 4,34-37) wskrzesił do życia Eutycha (w. 10). Następnie powrócił do sali na górze (w. 11), łamał chleb $i$ spożywat, a mówił jeszcze długo, bo aż

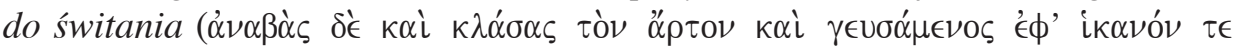

\footnotetext{
${ }^{50}$ Por. F. Bianchi, Atti degli Apostoli, 230-231.

${ }^{51}$ Por. W. Rakocy, Emaus - zmierzając na spotkanie ze zmartwychwstałym Panem ( $1 k$ 24,1335), 103-105.

${ }^{52}$ Różne interpretacje zestawia G. Rossé, Atti degli Apostoli, 713.
} 


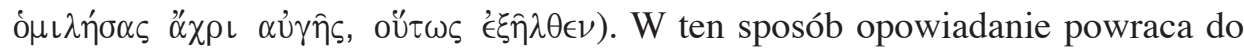
głównego wątku, jakim jest sprawowanie Eucharystii i głoszenie Słowa Bożego. Wprawdzie tekst wspomina samego Pawła i nikogo innego, ale być może Łukasz w ten sposób eksponuje osobę Pawła, głównego bohatera tej części Dziejów Apostolskich $^{53}$. Wcześniejszy kontekst wyraźnie wskazywał, że chodziło o wspólnotowe przeżywanie łamania chleba pod swoistego rodzaju ,przewodnictwem" Pawła. Narracja kończy się informacją, że Paweł wyruszył w drogę (w. 11), a wspólnota w Troadzie cieszyła się cudownym ocaleniem Eutycha (w. 12).

Znaczące wydaje się połączenie wątku sprawowanej Eucharystii przez Pawła i wspólnotę w Troadzie z cudem wskrzeszenia, przywrócenia do życia młodzieńca Eutycha. Przecież właśnie to w Eucharystii chrześcijanie wspominają zmartwychwstanie Pana, i to pierwszego dnia po szabacie, tzn. w niedzielę, która pozostaje pamiątką pustego grobu i spotkania ze Zmartwychwstałym. Eucharystia pozostaje zatem celebracją tajemnicy życia, które przezwycięża śmierć.

\section{3. Łamanie chleba w czasie podróży do Rzymu (27,33-38)}

Ostatnia wzmianka, którą możemy rozumieć jako odniesienie do Eucharystii, znajduje się w fragmencie opowiadającym podróż morską Pawła w kierunku Rzymu. Po odpłynięciu z Krety statek znalazł się w niebezpieczeństwie z powodu bardzo silnego wiatru. Załoga przez wiele dni zmagała się z żywiołem, ale wobec szalejącej nawałnicy traciła nadzieję ocalenia (w. 20). Paweł starał się podtrzymać morale załogi i zachęcał do ufności, że nikt nie zginie (w. 22), powołując się na wizję anioła Bożego, który obiecał Pawłowi, że uratuje się on sam i cała załoga statku (ww. 23-25).

Kiedy minął czternasty dzień, a żołnierze pozostawali bez posiłku i odpoczynku, Paweł zachęcał ich, aby się posilili, ufając całkowicie obietnicy anioła, że włos z głowy im nie spadnie ${ }^{54}$, tzn. że zostaną uratowani (w. 34). Przyjęcie zatem pokarmu miało służyć ocaleniu wszystkich. Tutaj Łukasz używa słowa

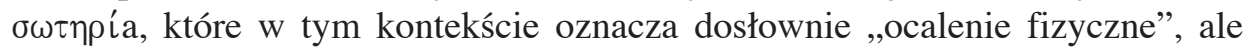
w Dziejach Apostolskich staje się terminem technicznym na określenie zbawienia w sensie religijnym (Dz 4,12; 7,25; 25,13; 26,47). Sam Paweł dał przykład (w. 35): wzią chleb, złożył Bogu dziękczynienie na oczach wszystkich

${ }^{53}$ Por. X. Léon-Dufour, Le partage du pain eucharistique selon le Nouveau Testament, Paris 1982, 33, przyp. 25.

${ }^{54}$ Jest to przysłowie hebrajskie: $1 \mathrm{Sm} \mathrm{14,45;} 2 \mathrm{Sm} \mathrm{14,11;} 1 \mathrm{Krl}$ 1,52; Łk 21,18. 


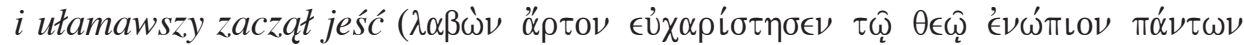

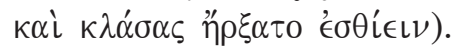

Naopisanie czynności PawłaAutor używa charakterystycznychzwrotów,które wcześniej pojawiają się w kontekście narracji o rozmnożeniu chleba w Łk 9,16

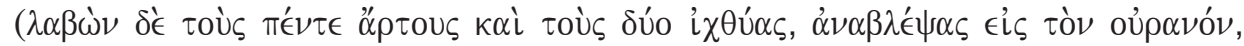

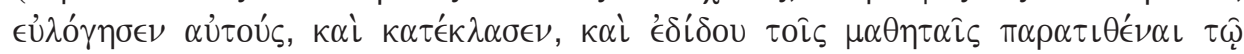

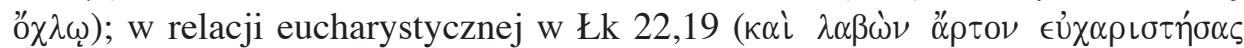
"є

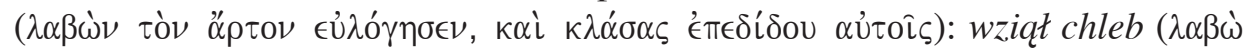

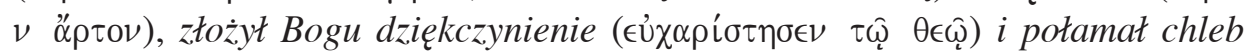

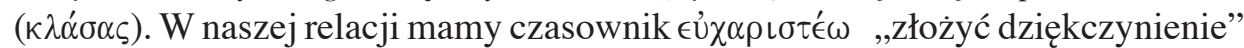

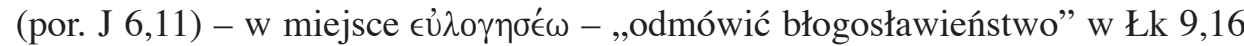
i 24,30, który bardziej odpowiada zwyczajom Paschy żydowskiej ${ }^{55}$. Zmiana ta może sugerować, że w zamiarze Autora opowiadane wydarzenie miało nawiązywać właśnie do tradycji ustanowienia Eucharystii w 22,19. Zwróćmy też uwagę, że niektóre manuskrypty tekstu zachodniego $(614,2147)$ uzupełniają paralelę z wyżej cytowanymi fragmentami, dodając: $\epsilon \pi\llcorner\delta\llcorner\delta o u \varsigma ~ \kappa \alpha \iota \eta \mu \iota \nu-$, ,i dał

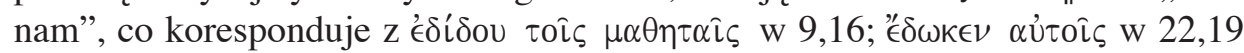

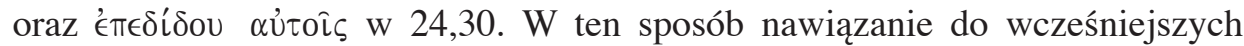
perykop stało się jeszcze bardziej czytelne i oczywiste. Dlaczego nie uczynił tego Łukasz? Być może dla podkreślenia, że posiłek Pawła - łamany chleb - miał inny wymiar niż posiłek pozostałych. Autor zdaje się przywiązywać wagę do faktu, że Paweł odmówił dziękczynienie, połamał i spożył chleb na oczach wszystkich ( $\epsilon \nu \omega ́ \pi เ \circ \nu \pi \alpha ́ \nu \tau \omega \nu)$. Nie chodziło tutaj wyłącznie o danie dobrego przykładu godnego naśladowania, ale „wygląda na to, że posiłek załogi statku nie posiadał tego samego charakteru, co posiłek Pawła. Jest więc do pomyślenia, że przyjęciu pokarmu przez Apostoła towarzyszyła intencja sprawowania Eucharystii, która oczywiście nie mogła być czytelna dla pogan, ujął ich jednak sposób zachowania więźnia" 56 . W ten sposób Łukasz opowiedział wydarzenie na statku, które nabrało znaczenia symbolicznego, bardzo czytelnego dla wspólnoty pierwotnego Kościoła. Zostało odczytane jako nawiązanie do Eucharystii, która była sprawowana także w momentach trudnych, zagrożenia życia i niebezpieczeństwie. Ciekawy wydaje się także związek łamania chleba i ocalenia życia (zbawienia). Gest Pawła przywrócił wszystkim otuchę, posilili się, nabrali ufności i nowej energii, która pozwoliła im przezwyciężyć niebezpieczeństwo, co przyniosło upragnione ocalenie życia.

\footnotetext{
${ }^{55}$ Por. J. Kudasiewicz, Eucharystia w życiu pierwotnego Kościoła, 29.

${ }^{56}$ W. Chrostowski, Eucharystia u pierwszych chrześcijan i dziś, 44.
} 


\section{Podsumowanie}

Na początku powiedzieliśmy, że Dzieje Apostolskie, choć opisują odległą historię pierwszych wspólnot chrześcijańskich, to przecież pozostają ciągle aktualnym Słowem Bożym, skierowanym do wyznawców Chrystusa wszystkich czasów. Spróbujmy zatem podsumować teraz nasze rozważania, zwracając uwagę na znaczenie Eucharystii już nie tylko dla wspólnot pierwszego wieku, ale także dla nas - współczesnych uczniów Jezusa.

1. Eucharystia jest paschalną pamiątka Pana, wspomnieniem uobecniającym całe Jego życie i dzieło (rozmnożenie chleba, Ostatnia Wieczerza), a szczególnie śmierć krzyżową i zmartwychwstanie. Celebrując to wydarzenie zbawcze, uczniowie Jezusa uczestniczą w Jego ofierze życia (łamany chleb oraz przelewana krew), ale przede wszystkim w Jego zwycięstwie nad śmiercią. Szczególnie Eucharystia niedzielna (pierwszy dzień po szabacie) jest ciągłym odkrywaniem tajemnicy pustego grobu i celebrowaniem życia, które przezwycięża śmierć. Jest uczeniem się dostrzegania obecności Zmartwychwstałego w życiu i razem z Nim przechodzenia (paschy) ze śmierci do życia.

2. Eucharystia ma zawsze wymiar wspólnotowy, jest sakramentem jedności. Ona tworzy wspólnotę Kościoła. Jest źródłem i znakiem owej jedności, której fundamentem jest sam Zmartwychwstały Chrystus. Uczta eucharystyczna staje się miejscem i sposobem przeżywania przez uczniów owej jedności z Chrystusem oraz braćmi. Jest zaproszeniem do ciągłej otwartości wobec drugiego człowieka, szczególnie najbardziej potrzebującego. Jest nie tylko dzieleniem chleba eucharystycznego, ale powinna przynaglać ucznia Jezusa do stawania się „,chlebem połamanym" dla braci.

3. Eucharystia jest znakiem eschatologicznym dokonanego zbawienia w Chrystusie. Winna być przeżywana w radości, wypływającej właśnie z owej świadomości, że celebruje się tajemnicę Boga zbawiającego człowieka. A jednocześnie chodzi zawsze o prostotę serca, tzn. pełne i ochocze zaangażowanie całego człowieka w misterium Eucharystii, co w rezultacie ma prowadzić do życia chrześcijańskiego, przepojonego duchem służby i ofiary.

4. Głęboko przeżywana Eucharystia ma wymiar misyjny. Jest skutecznym sposobem dawania autentycznego świadectwa ChrystusowiZmartwychwstałemu, które ma pociągać innych do Chrystusa.

5. Eucharystia znajduje swoje przedłużenie w modlitwie, której jest źródłem. Chrześcijanin wielbi Boga całym swoim życiem, które nabiera nowego sensu w świetle wydarzenia zbawczego przeżywanego w Eucharystii. Szczególnie w momentach trudnych, zagrożenia życia, poczucia zagubienia i niebezpieczeństwa taka modlitwa pomaga odnaleźć siłę do przezwyciężania 
trudności i umacnia nadzieję człowieka strapionego. W ten sposób Eucharystia staje się pokarmem podtrzymującym uczniów Jezusa w codzienności, pokarmem, który jest znakiem obecności Pana w każdej chwili życia chrześcijanina.

6. Eucharystia połączona jest ze słuchaniem i medytacją Słowa Bożego oraz nauczania apostolskiego. Umożliwia uczniom Jezusa wierne zachowanie pamięci o Jezusie. Jest sposobem odczytywania Słowa Bożego w konkretnych sytuacjach egzystencjalnych człowieka i wspólnoty Kościoła. Gest łamania chleba jest poprzedzony liturgią Słowa, która stanowi nie tylko przygotowanie do Eucharystii, ale jest niezbędnym kontekstem zrozumienia także polecenia Jezusowego: „to czyńcie na moją pamiątkę”. Właśnie słuchanie i medytowanie Słowa Bożego jest zachowywaniem i celebrowaniem ,pamiątki Pana”.

Na koniec warto przytoczyć fragment adhortacji Benedykta XVI: „Nasze wspólnoty, gdy celebrują Eucharystię, powinny być coraz bardziej świadome, że ofiara Chrystusa jest dla wszystkich i dlatego Eucharystia przynagla każdego weń wierzącego, by stawał się chlebem łamanym dla innych, a więc by angażował się na rzecz świata bardziej sprawiedliwego i braterskiego. Myśląc o rozmnożeniu chleba i ryb, winniśmy rozpoznawać, że Chrystus nadal, również i teraz, wzywa swych uczniów, by osobiście angażowali się: „Wy dajcie im jeść” (Mt 14,16), Naprawdę, powołaniem każdego z nas jest, byśmy wraz z Jezusem byli chlebem łamanym za życie świata" (Sacramentum caritatis, 88). 


\section{Sommario}

Gli Atti degli Apostoli ci narrano la storia delle prime comunità cristiane. Nel sommario che si legge in At 42-47 l'autore enumera quattro caratteristiche fondamentali e costitutive della comunità delle origini: assiduità nell'ascoltare l'insegnamento degli apostoli, nell'unione fraterna, nella frazione del pane e nelle preghiere. Per la prima volta troviamo qui la formula frazione del pane, che ritorna poi in At 20,7a.11 e At 27,35. Nell'articolo abbiamo indagato sul significato di quest'espressione. Alle soglie del cristianesimo quel gesto di spezzare il pane, caratteristico per il mondo semitico, non era solo equivalente a un pasto normale, preso in comune, ma designava una realtà nuova, grazie al riferimento diretto al gesto di Gesù, compiuto durante l'Ultima Cena. Con moltà probabilità, Luca aveva intenzione di parlarci del pasto del Signore e così nella sua opera la formula acquista un significato particolare, quasi tecnico, per designare una memoria viva di passione (il pane spezzato) e di risurrezione di Gesù Cristo (nel primo giorno della settimana), celebrata nei suoi tempi. Il gesto della frazione del pane diventa un gesto di riconoscimento misterico, come apparve evidente nella cena di Emmaus, raccontata in Lc 24,31-35. Anche oggi questo stesso gesto ha un significato molto profondo - come ci ricorda Benedetto XVI nella sua esortazione Sacramentum caritatis - „le nostre comunità, quando celebrano l'Eucarestia, devono prendere sempre più coscienza che il sacrificio di Cristo è per tutti e pertanto l'Eucarestia spinge ogni credente in Lui a farsi «pane spezzato» per gli altri, e dunque ad impegnarsi per un mondo più giusto e fraterno [...]. Davvero la vocazione di ciascuno di noi è quella di essere, insieme a Gesù, pane spezzato per la vita del mondo" (88). 
